\title{
Retraction Note: HAX-1 Promotes the Chemoresistance, Invasion, and Tumorigenicity of Esophageal Squamous Carcinoma Cells
}

\author{
Sa-jia Sun ${ }^{1} \cdot$ Long Feng ${ }^{2} \cdot$ Guo-qiang Zhao ${ }^{2} \cdot$ Zi-ming Dong $^{1}$
}

Published online: 12 July 2019

(c) Springer Science+Business Media, LLC, part of Springer Nature 2019

\section{Retraction Note to: \\ Dig Dis Sci (2012) 57:1838-1846 \\ https://doi.org/10.1007/s10620-012-2108-5}

The Editor-in-Chief has retracted this article [1] because Figure $3 \mathrm{c}$ appears to have been modified and reused as Figure $3 \mathrm{~d}$. An investigation by Zhengzhou University has confirmed that this figure was modified and reused. The data reported in this article are therefore unreliable. None of the authors has responded to any correspondence from the editor and the publisher about this retraction.

\section{Reference}

1. Sun S, Feng L, Zhao G, et al. HAX-1 promotes the chemoresistance, invasion, and tumorigenicity of esophageal squamous carcinoma cells. Dig Dis Sci. 2012;57:1838-1846. https://doi. org/10.1007/s10620-012-2108-5.

Publisher's Note Springer Nature remains neutral with regard to jurisdictional claims in published maps and institutional affiliations.
The original article can be found online at https://doi.org/10.1007/ s10620-012-2108-5.

Zi-ming Dong

dongzm@zzu.edu.cn

Sa-jia Sun

sajia_sun2010@yahoo.com.cn

Long Feng

flong01@163.com

Guo-qiang Zhao

zhaogq@126.com

1 Department of Pathophysiology, College of Basic Medical Sciences, Zhengzhou University, Zhengzhou 450001, Henan, People's Republic of China

2 Department of Microbiology and Immunology, College of Basic Medical Sciences, Zhengzhou University, Zhengzhou 450001, People's Republic of China 